\title{
Informed Consent to Immunization: The Risks and Benefits of Individual Autonomy
}

In the last two years there has been a dramatic movement toward disclosing the risks as well as the benefits of immunization to those vaccinated in mass immunization programs. The federal legislation establishing the 1976 swine flu immunization program included requireinents that recipients of the swine flu vaccine be fully inforined of the risks and benefits of immunization and that written consent forms be used. ${ }^{1}$ Informed consent procedures have also been introduced in polio iminunization programs administering vaccine purchased by the federal government, in order to comply with the contract with the vaccine manufacturer. ${ }^{2}$ The Center for Disease Control (CDC) has

1. 42 U.S.C.A. \& $247 b(j)$ (1) (F) (Supp. 1977). That section authorized:

The development [by the Secretary of Health, Education and Welfare], in consultation with the National Commission for the Protection of Human Subjects of Biomedical and Behavioral Research, and implementation of a written informed consent form and procedures for assuring that the risks and benefits from the swine flu vaccine are fully explained to each individual to whom such vaccine is to be administered. ... Such procedures shall include the information necessary to advice [sic] individuals with respect to their rights and remedies arising out of the administration of such vaccine.

Subject to certain qualifications, the United States accepted liability "for personal injury or death arising out of the administration of swine flu vaccine under the swine flu program and based upon the act or omission of a program participant ...." Swine flu vaccine manufacturers and distributors, public or private agencies providing inoculations, and medical or other health personnel assisting in the program were only considered "program participants" if the inoculation was provided without charge and the informed consent procedures were followed. 42 U.S.C.A. $\$ 247 \mathrm{~b}(\mathrm{k})(2)$ (Supp. 1977).

For a discussion of the tort claims procedures provided for in the Swine Flu Act, see Sparks v. Wyeth Laboratories, Inc., 431 F. Supp. 411 (W.D. Okla. 1977); Franklin \& Mais, Tort Law and Mass Immunization Programs: Lessons from the Polio and Flu Episodes, 65 CALIF. L. Rev. 754 (1977).

2. In September 1976, the federal government negotiated a contract to purchase polio vaccine from Lederle Laboratories, the one remaining manufacturer of live oral polio vaccine. The contract provided that the Department of Health, Education and Welfare would take appropriate steps:

(1) to provide patients, parents, or guardians with meaningful warnings as to the use, administration, and receipt of [the polio] vaccine in form and language understandable to them or (2) to assure administration of the vaccine on the basis of an individualized medical judgment by a physician that immuni-

zation is necessary and desirable for the patient [emphasis added].

As a condition of receiving a grant award from the federal governinent, each state must agree to carry out these contractual requirements and to use consent forms and proccdures developed by the Center for Disease Control [CDC], a federal government 
drafted informed consent forms for measles, mumps, rubella, and DPT ${ }^{3}$ vaccines and for the 1977-78 flu vaccine. ${ }^{4}$ The final versions of these forms will be used in all mass immunization programs in which vaccimes purchased by the federal government are administered. ${ }^{5}$

The movement toward disclosure is in large measure a result of an expansion of the manufacturer's legal duty to disclose the known risks of vaccination. ${ }^{6}$ Although these risks are generally remote, the argument for disclosure has prevailed in products liability suits alleging a breach of the manufacturer's duty to warn of the vaccine's risks. ${ }^{7}$ These cases conclude that when the decision to immunize is not accompanied by an "individualized medical judgment," the patient is entitled to full information on the risks and benefits of the procedure whenever such knowledge would present the patient with a "true choice judgment." As a result, it appears that manufacturers will soon require a formal undertaking in all purchase contracts that vaccinees in mass immunization programs will be warned of the risks inherent in the vaccimes. ${ }^{\circ}$

The disclosure required of private physicians ${ }^{10}$ administering vaccines is less well established. The cases establishing the manufac-

agency involved in the development, implementation, and evaluation of national vaccine programs. National Immunization Work Group on Consent, Report and Recommendations 30 (March 11, 1977), in Reports and Recommendations of the National Immunization Work Groups (March 15, 1977) (unpublished report submitted to the Office of the Assistant Secretary for Health) [hereinafter cited as Report on Consent]; National Immunization Work Group on Production and Supply, Report and Recommendations 2 (March 11, 1977), in Reports and Recommendations of the National Immunization Work Groups, supra; National Immunization Work Group on Research and Development, Report and Recommendations 6 (March 11, 1977), in Reports and Recommendations of the National Immunization Work Groups, supra.

3. DPT vaccine is the commonly-used abbreviation for the vaccine immunizing against diptheria, pertussis (whooping cough) and tetanus.

4. The July 1977 draft consent forms for measles, mumps, rubella, and DPT and the 1977-78 flu vaccine consent form are on file with the California Law Review. The draft forms may be revised before they are put into use. See note 99 infra.

5. Interview with Dr. James Chin, Chief of the Infectious Disease Section, State of California Department of Health, in Berkeley, California (Sept. 2, 1977).

6. See text at notes 33-50, infra.

7. E.g., Reyes v. Wyeth Laboratories, 498 F.2d 1264 (5th Cir.), cert. denied, 419 U.S. 1096 (1974); Davis v. Wyeth Laboratories, Inc., 399 F.2d 121 (9th Cir. 1968).

8. Reyes v. Wyeth Laboratories, 498 F.2d 1264, 1294 (5th Cir. 1974), cert. denied, 419 U.S. 1096 (1974); Davis v. Wyeth Laboratories, Inc., 399 F.2d 121, 129 130 (9th Cir. 1968).

9. Interview with Dr. James Chin, Chief of the Infectious Disease Section, State of California Department of Health, in Berkeley, California (Sept. 2, 1977).

10. Immunization occurs in a wide range of settings other than publicly sponsored mass immunization programs. For example, a patient may be immunized by a personal physician or by the house staff at a public or private hospital. These situations differ from mass immunizations in that the admimstration of the vaccine is performed by or under the supervision of a physician who has snfficient time and personal knowledge 
turer's duty to warn imply that when an individual receives a vaccination from a private physician, neither the inanufacturer nor the physician need warn the patient. ${ }^{11}$ This imphied limitation, based on the prescription drug rule and the intervening medical judgment, is, however, inconsistent with the policy of informed choice on which the cases are based. In fact, informed consent law does not permit physicians to substitute their judginent for that of their patients.

Informed consent case law emphasizes the individual's right to decide whether to submit to a medical procedure. To make an intelligent decision, the individual must be informed of the procedure's risks and benefits. Under the traditional medical standard, "customary medical practice" establishes the scope of the required disclosure. ${ }^{12}$ The recent changes in the practice of government-sponsored mass immunization programs should therefore substantially increase the scope of disclosure required of the private physician. ${ }^{13}$ The legal standard of disclosure applied in the more recent informed consent cases requires disclosure of "material facts."14 Because the risks and benefits of immunization are often closely balanced, ${ }^{15}$ the risks of vaccination will often be material and should be disclosed. Moreover, the rationale of the unodern informed consent cases justifies disclosure of risks and benefits even where the vaccination is required for school entry. ${ }^{16}$

This Cominent assesses the recent expansion of disclosure in mass immunization programs. Part I presents a case study of one atteinpt to assure informed consent in the context of the ill-fated swine flu prograin. Part II discusses the vaccine manufacturer's duty to warn under the law of products liability and analyzes its rationale. Part III sets out the recent case law of informed consent. It argues that both the inedical and legal standards of disclosure require warnings of the risks of vaccination. Finally, Part IV suggests ways in which both the scope and inanner of disclosure can and should be inproved in order to give substance to the ideal of informed individual choice.

\section{I}

INFormation Provided to SWINe Flu

VACCINE RECIPIENTS

The progressive developinent of consent forms used in the swine

of the patient to enable an individualized medical judgment as to whether vaccination is appropriate. This Comment refers to these situations as immunizations performed by a "private physician."

11. See text accompanying notes $42-46$ infra.

12. See text accompanying notes 53-54 infra.

13. See text accompanying notes 73-76 infra.

14. Canterbury v. Spence, 464 F.2d 786, 786-87 (D.C. Cir.), cert. denied, 409 U.S. 1064 (1972).

15. See text accompanying notes 77-79 infra.

16. See text accompanying notes 89-97 infra. 
flu vaccination program illustrates developing concepts of what informed consent to immunization should entail. ${ }^{17}$ In 1976, anticipating the danger of a nationwide outbreak of swine flu, Congress passed legislation providing for a national program of immunization against the disease. ${ }^{18}$ The enabling statute required the Secretary of Health, Education and Welfare, in consultation with the National Commission for the Protection of Human Subjects of Biomedical and Behavioral Research (the Commission) to produce an informed consent form for use with the swine flu vaccine. ${ }^{19}$ Responsibility for carrying out the immunization program was delegated to the Center for Disease Control (CDC), and CDC officials drafted the informed consent form. ${ }^{20}$ In response to changes suggested by Commission meinbers, the CDC thereafter drafted an additional introduction. Although Commisssion members still objected to the informed consent form and to the possibility of confusing vaccine recipients by usimg an introduction in addition to the origimal one page form, the consent form was used throughout the first phase of the program. ${ }^{21}$

This form ${ }^{22}$ was fairly detailed but gave the impression that flu vaccines, if not contramdicated, were safe. The only mention of possible severe or fatal reactions was contained in the section on contraindications. The form referred to the hazards of swine flu and Victoria flu; it stated that persons would not have adequate natural protection against swine flu and might not have adequate protection against Victoria flu. It did not state whether swine flu or Victoria

17. The changes also reflect the new data on the correlation between flu vaccination and the Guillain-Barre syndrome and the suggestions for changes in the forms made by the National Commission for the Protection of Human Subjects of Biomedical and Behavioral Research. U.S. Comptroller General, The Swine Flu Proliram: AN UNPRECEDENTED VentuRE in PREVENTIVE Medicine, H.R. Doc. No. 77-115, 95th Cong., 1st Sess. 23-28 (1977) [hereinafter cited as COMPTROLLER GENERAL's REPORT].

18. 42 U.S.C.A. $\$ 247 b(j)(1)(F)$ (Supp. 1977).

19. Id.

20. National Immunization Work Group on Health Information and Public Awareness, Report and Recommendations 5 (March 11, 1977) in Reports and Recommendations of the National Immunization Work Groups, supra note 2 [hereinafter cited as Report on Health Information].

21. Comptroller General's Report, supra note 17, at 23-24. Two consent forms were actually produced-one for the monovalent swine flu vaccine and one for the bivalent swine flu-A/Victoria flu vaccine. The bivalent vaccine consent form in cluded information on Victoria flu but in other respects was identical to the monovalent vaccine consent form. Both forms are on file with the California Law Review. This Comment traces the development of the bivalent vaccine consent form. Because the monovalent vaccine was not admimistered after the December 1976 moratorium on flu vaccines, the monovalent vaccine consent form was never revised. See notes 30-31 infra and accompanying text.

22. See July 1976 bivalent swine flu-A/Victoria flu conseut form, on file with the California Law Review. 
flu was likely to be a threat in the ensuing inonths. The forn also stated that "flu vaccine can be taken safely during pregnancy."

The "introduction" included as part of the early form contained several points of clarification and qualification. It pointed out that it was "possible that there could be [a swine flu] epidemic this winter. No one can say for sure." The form stated that Victoria flu "could occur again this winter." The introduction especially recommended the bivalent vaccine for "those with chronic medical problems and the elderly," who were said to "need annual protection against flu." Although the reverse side of the form stated that the vaccine could be taken safely during pregnancy, the introduction stated that no data specifically contraindicated flu vaccination during pregnancy. The introduction further indicated that a reaction more severe than a few days of fever or soreness was highly unlikely and that inore severe syinptoms should be brought to a doctor's attention. Finally, the introduction outlined the procedure for making claims against the federal government under the national swine flu immunization statute. ${ }^{23}$

Both sides of the consent form noted that by signing the form the recipient indicated an understanding of the risks and benefits of flu vaccination. The form also requested that the individual ask questions if he had any, and the consent statement indicated that the individual had had an opportunity to ask questions.

Notably, this early informed consent form did not give any specific warning of the remote risk of neurological disorders associated with the flu vaccine. A dozen reports of such a reaction to flu vaccines, including reports of three fatalities, had been received since the 1950's, but a causal hink with the flu vaccine had not been clearly established. ${ }^{24}$

As the iminunization prograin progressed, the absence of a swine flu outbreak, combined with the starthing, albeit statistically low, incidence of serious injury or death from the Guillain-Barre syndrome anong flu vaccine recipients caused many people, including public

23. The swine flu statute stated that the informed consent form must contain information about rights and remedies arising out of administration of the vaccine. 42 U.S.C.A. $\$ 247 b(j)$ (1) (F) (Supp. 1977).

In some states statutes were enacted limiting recovery for injury caused by the swine flu vaccine or its administration. These statutes were passed to persuade doctors, nurses, and local health departments concerned about potential liability to participate in the immunization program. See Franklin \& Mais, supra note 1, at 771-72; Ladimer, Legal and Regulatory Perspectives in Mass Immunization Programs, 1976 INS. L.J. 459, 461. California, for example, passed a statute exempting program participants from liability unless the injury resulted from "willful misconduct." CAL. Gov'T CoDE $\$ 856.6$ (a) (West Supp. 1977). The California version of the swine flu consent form advised vaccine recipients of this limitation on liability. This consent form is on file with the California Law Review.

24. COMPTROLIER GENERAL's RePORT, supra note 17 , at 25. 
health officials, to question the advisability of the swine flu immunization program..$^{25}$ These doubts culminated in a moratorium on all flu vaccines, imposed in December $1976 .^{28}$

In February 1977, a conference of the nation's leading epidemiologists was held, at which it was recommended that the moratorium be lifted for bivalent swine flu-A/Victoria flu vaccine, at least for certain groups of high risk individuals. ${ }^{27}$ The decision was not based on fear of swine flu but was based on the conferees' conclusion that the A/Victoria flu strain posed a clear threat. ${ }^{28}$ The bivalent vaccine contained the only available protection against A/Victoria flu. ${ }^{29}$ On the basis of this recommendation, the Secretary of Health, Education and Welfare lifted the moratorium for bivalent swine flu-A/Victoria flu vaccine. ${ }^{30}$

A new consent form was prepared when the moratorium was lifted. This form ${ }^{31}$ described the risks and benefits of the vaccine more precisely. Althougl similar in many ways to the earlier form, the revised consent form was particularly forthright about several items. It noted that: (1) the swine flu program had been suspended due to the fear of Guillain-Barre and the moratorium had been lifted solely to provide protection against Victoria flu to high-risk individuals; (2) very few cases of swine flu lhad in fact occurred; (3) "[i]t is not possible to estimate the risk to an individual of getting flu this year"; (4) the available evidence indicated that swine flu vaccine increases the hikelihood of suffering the Guillain-Barre syndrome by a factor of ten and that the syndrome could result in permanent paralysis or even death; (5) pregnant women should seek a doctor's advice about vaccination, since no specific data on the risks to pregnant women was

25. P. Parkman \& L. Harmison, Summary, Meeting Concerning Influenza Virus Vaccine Use 3 (Feb. 7, 1977) (unpublished summary of conference, on file with the California Law Review).

26. Id.

27. Comptroller General's Report, supta note 17 , at 24 . This decision was reached only after careful consideration of a variety of factors. The conferees were presented with evidence that the swine flu vaccine increased the risk of incurring Guillain-Barré syndrome by a factor of ten. They also considered the risks of not being immunized. With flu vaccines, vaccine experts must not only make "educated guesses" as to the likelihood of an influenza epidenic and the likely mortality rate if an epidemic were to occur but must also theorize as to what strain of flu virus might hit and to what extent available vaccines would protect against it. P. Parkman \& L. Harmison, supra note 25 , at 7-16.

28. P. Parkman \& L. Harmison, supra note 25, at 14-16.

29. Id. at 12 .

30. Id., Addendum. The moratorium remained in effect for the monovalent swine flu vaccine.

31. See February 1977 bivalent swine flu-A/Victoria flu consent form, on file with the California Law Review. 
available; and (6) "IF; YOU HAVE ANY QUESTIONS ABOUT FLU OR FLU VACCINE, PLEASE ASK."

The forms distributed during the swine flu program reflect the CDC's continuing efforts to fulfill the obligation imposed by the Swine Flu Act's informed consent requirements. The second form clearly shows greater precision and candor in the achievement of that goal. The question remains, however, whether such disclosure is or should be legally required in the absence of a statutory mandate. Recent developments in the law of products hability and informed consent suggest that detailed disclosure similar to that evidenced in the CDC's later form should now be required in all immunization programs.

II

\section{The Role of Products Liability Cases in the DEVELOPMENT OF INFORMED CONSENT TO IMMUNIZATION}

Although both federal and state governments have approached the issue of disclosure of the risks of immunization as a matter of "informed consent," ${ }^{22}$ the government's recent efforts to provide imfprmation on the risks and benefits of vaccines were largely a response to two products liability cases. ${ }^{33}$ In Davis $v$. Wyeth Laboratories, Inc. ${ }^{34}$ and Reyes v. Wyeth Laboratories, ${ }^{35}$ the plaintiffs had contracted polio after being vaccimated in mass immunization programs. Both decisions held, on similar theories, that the vaccine inanufacturer could be held liable for failure to warn the plaintiffs of the remote risk of contracting polio from the oral polio vaccime. ${ }^{36}$

These decisions have had a inajor impact on the information that is provided to potential vaccinees in mass immunization programs. Seeking to avoid liability for failure to warn, manufacturers will soon require the purchaser of vaccine to assume a contractual obligation to warn those vaccinated in mass immunization programs of the vaccine's risks. ${ }^{37}$ The developinent of the CDC's new battery of consent forms is therefore traceable to these opinions.

32. See COMPTROLIER General's Report, supra note 17, at 22-29; Report on Consent, supra note 2. The federal legislation creating the swine flu program referred specifically to "informed consent." 42 U.S.C.A. $\$ 247 b(j)$ (1)(F) (Supp. 1977).

33. 122 Cong. ReC. E4698-99 (daily ed. Aug. 26, 1976) (remarks of Rep. Rogers).

34. 399 F.2d 12I (9th Cir. 1968).

35. 498 F.2d 1264 (5th Cir.), cert. denied, 419 U.S. 1096 (1974).

36. Other courts have also held that the vaccine manufacturer has a duty to warn those vaccinated in mass immunization programs of the oral polio vaccine's risks. See, e.g., Stahlheber v. American Cyanamid Co., 45 S.W.2d 48 (Mo. 1970); Cunningham v. Charles Pfizer \& Co., 532 P.2d 1377 (Okla. 1974).

37. See notes $2 \& 33$ supra and accompanying text.

If a warning is not given and the manufacturer is held liable for failure to warn, 
In the Reyes and Davis cases, unlike most products liability cases finding a breach of the duty to warn, the required warning would not have reduced the chances of being mjured by the product. The risk of contracting polio from the oral polio vaccine is an "irreducible risk"- that is, a risk that, because it is not linked to an identifiable class of vaccine recipients, cannot be systematically avoided. ${ }^{38}$ But although a warning could not reduce the likelihood that an individual would contract polio if immunized, it might persuade the individual not to be immunized. $^{39}$ The decisions therefore appear to turn on preservation of individual freedom of choice. Indeed, Davis stressed the need for disclosure of risks so that the vaccine recipient will be able to make an "informed choice." 40 Reyes similarly stated that the consumer should be provided with information adequate to permit the weighing of the risks and benefits of the vaccine. ${ }^{41}$

Davis and Reyes deviate, however, from the policy of individual freedoin of choice im one respect. Both decisions distinguished immunizations administered by a private physician from those adininistered in a mass iminumization context. The manufacturer had contended that since a vaccine is a prescription drug the "prescription drug rule" should bar liability for failure to warn even in a mass immunization setting. ${ }^{42}$ The prescription drug rule permits a manufacturer to discharge its duty to warn of the risks of a prescription drug by informing physicians of the drug's risks and benefits, without informing the ultimate consumer. ${ }^{43}$ Davis and Reyes held that the prescription drug rule does not apply in the mass immunization context, since the vaccine is dispensed without an individualized medical judgment that the vaccine is necessary and desirable for the vaccime recipient. ${ }^{44}$ Where a physi-

these provisions would provide the mauufacturer with a contractual remedy for the health clinic's failure to disclose. It is possible that the manufacturer would not be held liable on the ground that Davis required the manufacturer either to give warnings or to obligate the purchaser to give warnings. $399 \mathrm{F.2d}$ at 131. If the manufacturer reasonably believed that the purchaser, having assumed the obligation, would fulfill it, the manufacturer might be relieved of hability.

38. See Reyes v. Wyeth Laboratories, $498 \mathrm{~F} .2 \mathrm{~d}$ at 1279.

39. A warning might also cause the vaccine recipient to seek prompt treatment if illness followed immunization. In Reyes, for example, the plaintiff's mother continued to have her child vaccinated after the child had already contracted polio. $498 \mathrm{~F} .2 \mathrm{~d}$ at 1282.

40. 399 F.2d at 129.

41. 498 F.2d at 1276 .

42. Reyes v. Wyeth Laboratories, 498 F.2d at 1275; Davis v. Wyeth Laboratories, Inc., 399 F.2d at 130 . The same argument was advanced, and rejected, in Cunningham v. Charles Pfizer \& Co., 532 P.2d 1377, 1381 (Okla. 1974).

43. Reyes v. Wyeth Laboratories, 498 F.2d at 1276; Davis v. Wyeth Laboratories, Inc., 399 F.2d at 130 .

44. Reyes v. Wyeth Laboratories, 498 F.2d at 1276-77 \& 1295; Davis v. Wyeth Laboratories, Inc., 399 F.2d at 131. Accord, Cunningham v. Charles Pfizer \& Co., 532 P.2d 1377, 1381 (Okla. 1974). 
cian is involved in administering the immunization, however, Davis and Reyes assume that the inanufacturer does not have a duty to inform the patient of the risks. ${ }^{45}$ Both cases imply that because the doctor, acting as a "learned intermediary," makes an "individualized medical judgment" the patient does not need to be informed.48

The justification for the prescription drug rule is strongest when the doctor can make the use of the product safer because of knowledge and continuing supervision of the patient. ${ }^{47}$ But since the risks $\mathrm{m}$ volved in Reyes and Davis could not be linked in advance to any particular class of patients, individualized medical knowledge of the patient could not have decreased these risks. If, as the courts argued, the patient has a right to receive the information necessary to make a "true choice judgment," 48 that right to be informed would appear to be the same whether the vaccination is administered in a mass immunization program or by a private physician. Thus, it is illogical to impose on manufacturers a duty to enable informed choice in the mass immunization setting without imposing a similar duty when a private physician administers the vaccime. ${ }^{49}$ This illogical distinction, drawn

45. Reyes v. Wyeth Laboratories, 498 F.2d at 1295; Davis v. Wyeth Laboratories, Inc., 399 F.2d at 130-31. In accordance with the Reyes holding, the remaining manufacturer of oral polio vaccine instituted a contractual requirement that either the vaccine recipient must sign a consent form or a physician must certify that he made an individualized medical judgment that immunization was necessary and desirable for the patient. See note 2 supra.

46. Reyes v. Wyeth Laboratories, 498 F.2d at 1276. Davis, after stating that a patient is not obliged to submit to the risks inherent in unavoidably unsafe drugs, concluded: "If he is to submit it must be by his voluntary and informed choice or a choice made on his behalf by his physician." $399 \mathrm{F.2d}$ at 129 (emphasis added). Reyes similarly referred to "the right of an individual to choose and control what risk he will take, in the absence of an individualized medical judgment by a physician familiar with his needs and susceptibilities." 498 F.2d at 1294 (emphasis added). One court has in fact explained the prescription drug rule by reasoning that:

[w] ere the patient to be given the complete and highly technical information on the adverse possibility associated with the use of the drug, he would have no way to evaluate it, and in his limited understanding he might actually object to the use of the drug, thereby jeopardizing his life.

Carmichael v. Reitz, 17 Cal. App. 3d 958, 989, 95 Cal. Rptr. 381, 400 (2d Dist. 1971). This analysis ignores the fact that under informed consent doctrine the doctor may have a duty to inform the patient of the drug's risks, and cannot withhold the information on the ground that the patient would refuse the drug if informed. See notes 68-72 \& 81 infra and accompanying text.

47. The rule rests in part on the ability of the physician to determine his patient's individual needs and susceptibilities. Davis v. Wyeth Laboratories, Inc., 399 F.2d at 130.

48. Reyes v. Wyeth Laboratories, 498 F.2d at 1294; Davis v. Wyeth Laboratories, Inc., $399 \mathrm{~F} .2 \mathrm{~d}$ at 129-30.

49. Manufacturers could conceivably be required to direct warnings to consumers as well as to physicians. See, e.g., 21 C.F.R. $\$ 310.501$ (a) (1977) (information on risks and benefits of oral contraceptives inust be provided by the manufacturer, directed to patients, rather than solely to physicians). 
in the context of products liability law, should not be interpreted to mean that the private physician does not have a duty to disclose the risks of vaccines under the law of informed consent. ${ }^{50}$ The inplication in Davis and Reyes that a doctor may judge the risks for the patient is inconsistent with the informed consent case law.

\section{III \\ Disclosure Required by THE Doctrine OF INFORMED CONSENT}

\section{A. The Legal Standard and the Medical Standard of Disclosure}

The doctrine of informed consent rests on the right of each individual to decide whether to subinit to a medical procedure. ${ }^{51}$ To enable the patient to make an intelligent choice, the doctor must explain what the procedure involves and what benefits and risks it entails. Although some patients might desire to be informed of all risks of a medical procedure, the informed consent case law does not require such broad disclosure. ${ }^{52}$ Two standards of disclosure currently prevail. The traditional "inedical standard," generally characterized as the majority rule, ${ }^{53}$ views disclosure as a natter of medical judgment. The

50. See, e.g., Marsh v. Arnold, 446 S.W.2d 949 (Tex. Civ. App. 1969).

51. [Informed consent] is not a mere rubberstamp of the physician's recommendation. Each man is considered master of his own body and may request or prohibit even lifesaving surgery. The law will not allow a physician to substitute his own judgment, no matter how well founded, for that of his patient.

Collins v. Itoh, 503 P.2d 36, 40 (Mont. 1972). See also Canterbury v. Spence, 464 F.2d 772, 781 (D.C. Cir.), cert. denied, 409 U.S. 1064 (1972); Cobbs v. Grant, 8 Cal. 3d 229, 243, 502 P.2d 1, 10, 104 Cal. Rptr. 505, 514 (1972); Natanson v. Kline, 186 Kan. 393, 406-07, 350 P.2d 1093, 1104 (1960), rehearing denied, 187 Kan. 186, 354 P.2d 670 (1960); Wilkinson v. Vesey, 110 R.I. 606, 624, 295 A.2d 676, 687 (1972).

Failure to obtain informed consent is generally termed "negligence" and may result in liability for all damages proximately resulting from the failure to disclose. See, e.g., Canterbury v. Spence, 464 F.2d at 790; Shetter v. Rochelle, 2 Ariz. App. 358, 367, 409 P.2d 74, 83 (1965), modified, 2 Ariz. App. 607, 411 P.2d 45 (1966). The failure to disclose does not create an unreasonable risk of harm, however, and thus is unlike ordinary negligence. The duty to disclose is actually based on the desire to preserve individual autonomy.

52. See Canterbury v. Spence, 464 F.2d 772, 786 (D.C. Cir.), cert. denied, 409 U.S. 1064 (1972); Getchell v. Mansfield, 260 Or. 174, 489 P.2d 953 (1971); Wilkinson v. Vesey, 110 R.I. $606,627,295$ A.2d 676, 689 (1972).

If the patient wishes to be informed of risks beyond the scope of the required disclosure, the patient must inquire about other risks of the procedure. Mason v. Ellsworth, 3 Wash. App. 298, 313, 474 P.2d 909, 919 (1970).

53. See Canterbury v. Spence, 464 F.2d 772, $783-85$ (D.C. Cir.), cert. denied, 409 U.S. 1064 (1972); Cobbs v. Grant, 8 Cal. 3d 229, 241, 502 P.2d 1, 9, 104 Cal. Rptr. 505, 513 (1972); Wilkinson v. Vesey, 110 R.I. 606, 621-22, 295 A.2d 676, 68687 (1972). Although these cases stated that the majority of jurisdictions follow the medical standard, the legal standard is rapidly gaining support. See note 55 infra and 
scope of the required disclosure is based on the customary practice within the medical community. ${ }^{54}$

In recent years, however, many influential jurisdictions have adopted a "legal standard" for disclosure. ${ }^{55}$ In Canterbury v. Spence, ${ }^{50}$ for example, the District of Colunbia Circuit Court of Appeals held that a doctor is required to disclose the "material" risks and benefits of and the alternatives to the procedure. The Canterbury court argued that it is often very difficult to establish a customary practice regarding disclosure of the risks of a particular medical procedure, that the inedical standard entrusts too mucl discretion to the medical profession, and that a medical standard is inconsistent with the view that the doctor's judgment may not always coincide with the patient's. ${ }^{57}$

accompanying text. The trend toward the legal standard is not uniform, however. Many jurisdictions still adhere to a medical standard. See, e.g., Riedisser v. Nelson, 111 Ariz. 542, 534 P.2d 1052 (1975); Martin v. Bralliar, 540 P.2d 1118 (Colo. App. 1975); Coleman v. Garrison, 327 A.2d 757 (Del. Super. 1974); Butler v. Berkeley, 25 N.C. App. 325, 213 S.E.2d 571 (1975).

54. See, e.g., Riedisser v. Nelson, 111 Ariz. 542, 542-43, 534 P.2d 1052, 105455 (1975); Coleman v. Garrison, 327 A.2d 757, 762-63 (Del. Super. 1974); Wilson v. Scott, 412 S.W.2d 299, 302 (Tex. 1967). See also Canterbury v. Spence, 464 F.2d 772, 783 (D.C. Cir.), cert. denied, 409 U.S. 1064 (1972).

Informed consent cases often define the medical standard in terms of what a "reasonable medical practitioner" would disclose under the same or similar circumstances. See, e.g., Collins v. Itoh, 503 P.2d 36, 40 (Mont. 1972); Wilson v. Scott, 412 S.W.2d 299, 302 (Tex. 1967). This is not a "reasonable person" test, however, for the cases emphasize the need to defer to medical judgment and therefore base the duty to disclose on adherence to standard medical practice. See W. Prosser, The LAW of Torts $\$$ 32, at 165 (4th ed. 1971).

In jurisdictions applying the medical standard, plaintiff generally must present expert testimony to establish the standard of disclosure. See, e.g., Nishi v. Hartwell, 52 Haw. 188, 473 P.2d 116 (1970); Collins v. Itoh, 503 P.2d 36 (Mont. 1972); Wilson v. Scott, 412 S.W.2d 299 (Tex. 1967). Canterbury noted the importance of expert testimony of medical custom when a medical standard is applied: "As in much malpractice litigation, recovery im nondisclosure lawsuits has hinged upon the patient's ability to prove through expert testimony that the physician's performance departed from medical custom." 464 F.2d at 791 (footnote omitted).

55. See, e.g., Canterbury v. Spence, 464 F.2d 772 (D.C. Cir.), cert. denied, 409 U.S. 1064 (1972); Riedinger v. Colburn, 361 F. Supp. 1073 (D. Idaho 1973) (concluding that the Idaho Supreme Court, if faced with the issue, would adopt the legal standard); Cobbs v. Grant, 8 Cal. 3d 229, 502 P.2d 1, 104 Cal. Rptr. 505 (1972); Getchell v. Mansfield, 260 Or. 174, 489 P.2d 953 (1971); Wilkinson v. Vesey, 110 R.I. 606, 295 A.2d 676 (1972); Miller v. Kennedy, 11 Wash. App. 272, 522 P.2d 852 (1974), aff'd per curiam, 85 Wash. 2d 151, 530 P.2d 334 (1975); Scaria v. St. Paul Fire \& Marine Ins. Co., 68 Wis. 2d 1, 227 N.W.2d 647 (1975).

56. 464 F.2d 772, 786-87 (D.C. Cir.), cert. denied, 409 U.S. 1064 (1972).

57. Id. at 783-85. In Cobbs v. Grant, 8 Cal. 3d 229, 502 P.2d 1, 104 Cal. Rptr. 505 (1972), the California Supreme Court followed Canterbury's lead, adopting a legal standard and agreeing with Canterbury's reasoning that "[u]nlimited discretion in the physician [under the medical standard] is irreconcilable with the basic right of the patient to make the ultimate informed decision." 8 Cal. 3d at 243, 502 P.2d at 10, 104 Cal. Rptr. at 514. 
The legal standard seeks to assure that the patient will receive all information necessary to an informed decision. 58 To that end, "all risks potentially affecting the decision must be unmasked."59 Canterbury phrased the materiality test in terms of whether a "reasonable person, im what the physician knows or should know to be the patient's position, would be likely to attach significance to the risk or cluster of risks." "60 Under this test a broad range of risks could be considered "material," for, as Canterbury pointed out, a risk that viewed alone might not determine a person's decision could be significant when viewed in conjunction with other risks. ${ }^{61}$ Although the Canterbury

58. See, e.g., Canterbury v. Spence, 464 F.2d at 787; Cobbs v. Grant, 8 Cal. 3d 229, 245, 502 P.2d 1, 11, 104 Cal. Rptr. 505, 515 (1972); Wilkinson v. Vesey, 110 R.I. 606, 627-28, 295 A.2d 676, 689 (1972); Miller v. Kennedy, 11 Wash. App. 272, 282, 522 P.2d 852, 860 (1974), aff'd per curiam, 85 Wash. 2d 151, 530 P.2d 334 (1975).

59. Canterbury v. Spence, 464 F.2d at 786-87.

It should be noted that under Canterbury and Cobbs v. Grant the physician could still be held liable for failure to follow the medical standard of disclosure even where a legal standard has been adopted. See Canterbury v. Spence, 464 F.2d at 783; Cobbs v. Grant, 8 Cal. 3d 229, 244-45, 502 P.2d 1, 11, 104 Cal. Rptr. 505, 515 (1972). The two standards call for somewhat different trial tactics. Under the medical standard, expert testimony would be directed to showing the customary practice regarding disclosure; under the legal standard an expert would testify as to the identity and nature of the risks, any justifications for nondisclosure (such as an emergency), and whether the plaintiff's injury actually resulted from the medical procedure. Canterbury v. Spence, 464 F.2d at 791-92. See also Wilkinson v. Vesey, 110 R.I. 606, 624-26, 295 A.2d 676, 688 (1972); Mason v. Ellsworth, 3 Wash. App. 298, 312, 474 P.2d 909, 919 (1970).

60. 464 F.2d at 787 (footnote omitted). This test of materiality was also adopted in Wilkinson v. Vesey, 110 R.I. 606, 627, 295 A.2d 676, 689 (1972) and Miller v. Kennedy, 11 Wash. App. 272, 282-83, 522 P.2d 852, 860 (1974), aff'd per curiam, 85 Wash. 2d 151, 530 P.2d 334 (1975). The court also noted that in assessing the materiality of a risk both the severity of the risk and the likelihood of its occurrence should be considered. Id. at 788 . Accord, Getchell v. Mansfield, 260 Or. 174, 180, 489 P.2d 953, 956 (1971); Wilkinson v. Vesey, 110 R.I. 606, 627-28, 295 A.2d 676, 689 (1972).

61. "[W]e do not subscribe to the view that only risks which would cause the patient to forego treatment must be divulged . . . for such a principle ignores the possibility that while a single risks might not have that effect, two or more might do so." Canterbury v. Spence, 464 F.2d at 788 n.89.

Although Canterbury stressed the need for disclosure of all material facts in order to enable a patient to make an individualized evaluation of the risks and benefits, the decision departed from the emphasis on individual decisionmaking by adopting an "objective test" of causation. Under this test, if the "prudent patient" would have chosen to undergo the procedure when fully informed of the risks involved, the failure to disclose is not regarded as having caused the injury. 464 F.2d at 790-91. Prior informed consent cases had phrased the causation issue in terms of whether the individual plaintiff would have submitted to the procedure had adequate disclosure been made. See, e.g., Shetter v. Rochelle, 2 Ariz. App. 358, 367, 409 P.2d 74, 83 (1965), modified, 2 Ariz. App. 607, 411 P.2d 45 (1966); Mason v. Ellsworth, 3 Wash. App. 298, 313, 474 P.2d 909, 919 (1970). Canterbury's causation standard appears to make recovery more difficult.

Causation issues in vaccine informed consent cases are likely to be complex. The 
court apparently viewed materiality as turning on the informational needs of a reasonable patient, a strong argument can be inade that if a physician knows or should know that a patient particularly fears a certain risk, that risk should also be considered material for that patient." ${ }^{02}$ Requiring attention to the individual's apparent personal preferences is consistent with the policy of individual choice that underlies the doctrine of informed consent.

Materiality under the legal standard is an inherently flexible concept. In Cobbs v. Grant, ${ }^{63}$ however, the Califorma Supreme Court appears to have adopted a per se limitation upon the duty of disclosure for certain "simple" procedures. The court stated:

[T] here is no physician's duty to discuss the relatively minor risks inherent in common procedures, when it is common knowledge that such risks inherent in the procedure are of very low incidence. . . . [A] disclosure need not be made if the procedure is simple and the danger remote and commonly appreciated to be remote. ${ }^{64}$

The court concluded that no warning is required with these common procedures beyond inquiry as to whether the treatment inight be contraindicated. ${ }^{\mathrm{os}}$

The Cobbs standard purports to achieve rough coinpliance with the materiality standard of Canterbury. The court assumes that if a risk is "remote and commonly appreciated to be remote," then it is not "material." The materiality standard, however, does not depend solely on the character of the risk, but rather on a comparison of the risks and benefits of the procedure and an assessment of the risks of available alternatives. If the benefits as well as the risks of the procedure are slight, so that the risks and benefits are closely balanced, then "remote risks" are clearly material and should be disclosed. ${ }^{80}$

initial question of whether the vaccination actually caused the injury will often be a hotly contested issue. See, e.g., Reyes v. Wyeth Laboratories, 498 F.2d 1264 (5th Cir.), cert. denied, 419 U.S. 1096 (1974). If an "objective test" is then applied to determine whether the failure to disclose caused the injury, the question arises whether a purely statistical comparison of risks and benefits would be determinative. A further question arises as to whether the benefits to society of widespread immunization should be weighed in the balance. A thorough analysis of issues of causation and liability is beyond the scope of this Comment.

62. Some language in Canterbury supports this approach. At one point in the opinion the court stated that the reasonableness of the disclosure should be judged "in terms of what [the physician] knows or should know to be the patient's informational needs." 464 F.2d at 787. However, the court later stated the test in terms of what a reasonable patient would wish to know. Id. Under either approach the doctor is not required to speculate about the patient's particular interests or fears.

63. 8 Cal. 3d 229, 502 P.2d 1, 104 Cal. Rptr. 505 (1972).

64. Id. at 244-45, 502 P.2d at 11-12, 104 Cal. Rptr. at 515-16.

65. Id. at $244,502 \mathrm{P} .2 \mathrm{~d}$ at 11,104 Cal. Rptr. at 515.

66. It may well be that the public often does not appreciate that a risk is remote 
The Cobbs court may not have intentionally diverged from the general guidelmes governing the legal standard when it distinguished between simple and complicated procedures. A subsequent passage states: "Thus the test for determining whether a potential peril must be divulged is its materiality to the patient's decision." logical standard to apply, this is the language in Cobbs that should be followed.

Some cases have suggested a second limitation upon the duty to disclose, argumg that the doctor must above all act in the best interests of his patient. ${ }^{68}$ Thus it has been stated that if the doctor reasonably believes that disclosure of material risks will frighten the patient out of a medically recommended treatment, then disclosure is not required. ${ }^{60}$ The leading cases, however, consistent with the concern for individual choice, have emphasized that the privilege to withhold information must be "carefully circumscribed" and have rejected "the paternalistic notion that the physician may remain silent simply because divulgence might prompt the patient to forego therapy the physician feels the patient really needs."70 Canterbury, for example, would permit nondisclosure only in the event of an emergency or where disclosure would dangerously increase the risks to the patient. ${ }^{71} \mathrm{Cobbs}$, accepting this approach, stressed that the doctor must show good cause for his professed fear that disclosure would have caused the patient to suffer from a dangerous degree of anxiety. ${ }^{72}$

but rather is not aware of the risk at all. If the Cobbs exception were interpreted to allow nondisclosure in such cases, this would be inconsistent with the purpose of informed consent.

67. 8 Cal. 3d at 245, 502 P.2d at 11, 104 Cal. Rptr. at 515.

68. See, e.g., Shetter v. Rochelle, 2 Ariz. App. 358, 366, 409 P.2d 74, 82 (1965), modified, 2 Ariz. App. 607, 411 P.2d 45 (1966); Getchell v. Mansfield, 260 Or. 174, 181-82, 489 P.2d 953, 956 (1971).

69. Zebarth v. Swedish Hosp. Medical Center, 81 Wash. 2d 12, 25-26, 499 P.2d 1, 9-10 (1972). Many cases note the possibility that too full a disclosure of risks could constitute bad medical practice. See, e.g., Shetter v. Rochelle, 2 Ariz. App. 358, 366, 409 P.2d 74, 82 (1965), modified, 2 Ariz. App. 607, 411 P.2d 45 (1966); Nichi v. Hartwell, 52 Haw. 188, 197, 473 P.2d 116, 121 (1970); Williams v. Menehan, 191 Kan. 6, 8, 379 P.2d 292, 294 (1963); Natanson v. Kline, 186 Kan. 393, 406, 350 P.2d 1093, 1103 (1960), rehearing denied, 187 Kan. 186, 354 P.2d 670 (1960). Generally these comments seem to be based on the fear that the apprehension caused by the disclosure would be harınful to the patient. One case, however, specifically referred to the theory that a disclosure of risks that caused a patient to refuse a procedure even though the risk revealed was "ninimal" might serve as the basis of a malpractice claim. Mason v. Ellsworth, 3 Wash. App. 298, 309, 474 P.2d 909, 917 (1970). It would seem that a doctor who made a reasonable effort to describe accurately the procedure's risks and benefits could not then be held liable if the patient refused the procedure on the basis of that disclosure.

70. Canterbury v. Spence, 464 F.2d at 789.

71. Id.

72. $8 \mathrm{Cal}$. 3d at 246,502 P.2d at 12,104 Cal. Rptr. at 516. The reasoning of these cases suggests that other, less powerful justifications for nondisclosure should also 


\section{B. Applying the Standards of Disclosure to the Context of Vaccination}

Prior to the swine flu statute a plaintiff who was injured by a vaccine but was unable to show that the vaccine was contraindicated would probably have found it very difficult to establish a breach of the medical standard of disclosure. Under the medical standard, the scope of the required disclosure is determined by custonnary medical practice, and in most instances the practice was nondisclosure. The federal government did not require public health programs receiving vaccines from the federal government to use CDC informed consent forms prior to the swine flu immunization program. ${ }^{73}$ Although some state and county health officials may have developed their own methods of disclosing the risks and benefits of particular vaccines, there apparently was no general practice of providing vaccine recipients with the detailed information now included in the CDC's informed consent forms. ${ }^{74}$ Presuinably there has always been some method of checking for contraindications, but it is not likely that this alone would provide much information to vaccine recipients.

Similarly, in the private physician setting there has probably been no general practice of disclosing the risks of vaccines. Physicians presumably check to determine that a vaccine is not contraindicated before administering it, and therefore may have explained the greater risks associated with the vaccine when certain conditions are present-the reducible risks of vaccines. Yet it is unlikely that physicians have customarily outlined the remote irreducible risks associated with vaccines-for exainple, the risk of contracting polio from the Sabin polio vaccine. The informed consent provisions of the swine flu statute may, however, have prompted physicians to provide nore information about vaccine risks. ${ }^{75}$

be rejected. For example, the cost of obtaining informed consent should not justify nondisclosnre. The process clearly is time-consuming, and therefore costly, particularly in mass immunization programs where written consent forms for a variety of vaccines will generate new paperwork for public health agencies. However, if a doctor's assessment of the patient's best interests is not sufficient to permit nondisclosure, then the cost of obtaining consent can hardly provide an excuse.

73. Report on Consent, supra note 2, at 28-29. In May 1976, however, the CDC did distribute a recommended vaccime consent form, entitled Vaccines and Immunization. Id. This document provided a rather brief description of the risks and benefits of DPT, measles, mumps, rubella, and oral polio vaccine. The polio section did not contain any information about the Salk killed-virus polio vaccine. This early consent form is on file with the California Law Review.

74. Report on Consent, supra note 2, at 28-31.

75. If a private physician administering the swine flu vaccine complied with the swine flu immunization program's iuformed consent procedures and did not charge for the vaccine or its administration, then the Swine Flu Act's tort claims procedures would apply in any suit against the doctor alleging injury arising out of the vaccination. Un- 
The institution of more widespread informed consent procedures should aid a plaintiff suing under a medical standard of disclosure. Now that public health programs are instituting informed consent procedures as a general practice, a plaintiff vaccinated at a public health clinic would have substantial evidence of the prevailing inedical practice. A plaintiff vaccinated by a private physician could argue that the level of disclosure at a public health clinic indicates what a private doctor should disclose. The primary distinction between public and private settings is that the private physician directs more attention to the mdividual patient. The patient's need for information remaims the same im both settings, however, and the informed consent decisions plainly state that the doctor's judgment is not to be substituted for that of the patient. ${ }^{76}$

Under the legal standard, the question whether disclosure should be required turns on an assessment of the materiality of the risks imvolved. The risks of vaccmation are admittedly remote for virtually all vaccimes. But because the incidence of contagious diseases has declined greatly due to immunization programs, ${ }^{77}$ the individual's chances of being seriously injured by a vaccine may exceed the likelihood that serious imjury will result from contracting the disease. ${ }^{78}$ Where the balance between risks and benefits to the individual is close, this information is inaterial to an informed decision on the value of the procedure to the vaccinee. ${ }^{79}$

Widespread disclosure in public health immunization programs will also provide strong evidence that the risks of immunization are material. ${ }^{89}$ The careful study of the problem of the extent of disclosure

der these provisions, the United States would substitute itself as the party defendant but conld later sue the physician for any damages recovered by the plaintiff that were attributable to the physician's negligence. 42 U.S.C.A. $\$ \S 247 \mathrm{~b}(\mathrm{k})(1)(\mathrm{B})-(2)(\mathrm{B})$, $247 \mathrm{~b}(\mathrm{k})(7)$ (Supp. 1977). The states were obligated to send copies of the swine flu informed consent form to all private physicians receiving flu vaccine. Report on Consent, supra note 2, at 29.

76. See cases cited in note 51 supra.

77. See National Imınunization Work Group on Policy, Report and Recommendations 1 \& Table 1 (March 11, 1977), in Reports and Recommendations of the National Immunization Work Groups, supra note 2 [hereinafter cited as Report on Policy].

78. Report on Consent, supra note 2, at 36 . In Davis v. Wyeth Laboratories, Inc., 399 F.2d at 130, the conrt noted: "[A]ppellant's risk of contracting the disease [polio] without immunization was about as great (or small) as his risk of contracting it from the vaccine. Under these circumstances we cannot agree with appellee that the choice to take the vaccine was clear."

79. It should also be recognized that the vaccine recipient is a healthy individual, not a person with an existing ailment who must undergo some form of treatinent in order to mitigate or cure the illness. In Davis the court emphasized this point. 399 F.2d at 130 .

80. In Canterbury v. Spence, 464 F.2d at 785, the court noted that prevailimg medical practice has evidentiary value in determining the appropriate legal standard of professional conduct. 
by the CDC and other government agencies and the resulting decision to disclose very remote risks provide substantial evidence that the information should be disclosed by private physicians. At the very least, what is disclosed in the medical community will mevitably affect juries' expectations of what should "reasonably" be disclosed.

It could be argued that disclosure of the risks of vaccination is unwise because it will deter persons from obtaining immunizations that would be medically advisable. Even if disclosure of known risks and benefits would cause an individual who would have benefitted from immunization to refuse to be vaccimated, this would not provide a ground for nondisclosure under the leading informed consent cases. Both Canterbury and Cobbs have limited the privilege of nondisclosure to emergencies or situations where the warning itself would result in a dangerous mcrease in the risks to the patient. ${ }^{81}$ With most immunizations it is highly unlikely that these exceptions will apply.

The argument that knowledge of the risks of vaccimes would generally deter imdividuals from being immunized and would thus hamper the success of mass immunization programs would also fail under current standards for disclosure. In Canterbury, the physician argued that disclosure of remote risks would deter too many people from having valuable surgery. The court rejected the doctor's argument, since it referred to patients im general rather than to any unusual circumstances mvolved in the plaimtiff's case. ${ }^{82}$ In the face of a similar claim, ${ }^{83}$ the court in Reyes affirmed "the right of the individual to choose and control what risk he will take." 84

Moreover, if the disclosure fairly portrays risks and benefits it should not deter a substantial number of people from being vaccinated. ${ }^{85}$ Admittedly, participation in the swine flu program did de-

81. Canterbury v. Spence, 464 F.2d at 789; Cobbs v. Grant, 8 Cal. 3d at 246 , 502 P.2d at 12, 104 Cal. Rptr. at 516.

82. 464 F.2d at 794 n.138.

83. Reyes v. Wyeth Laboratories, 498 F.2d at 1293.

84. Id. at 1294 .

85. If the disclosure made is complete and not misleading and experience with informed consent to immunization nevertheless shows that disclosure results in a drop in participation that seriously endangers the public health, various remedies could be considered. One commentator, discussing the drug manufacturer's duty to warn of risks. suggested that if a compensation system for mass immunization program victims were adopted, participation could then be encouraged by assuring vaccine recipients of compensation for any vaccine-related injury. Franklin \& Mais, supra note 1, at 773-74. Although a compensation program can be supported on other grounds, it is questionable how much encouragement would actually be provided by such an assurance.

Another commentator, also discussing the manufacturer's duty to warn, suggested that the public health considerations involved might justify an exception to the duty to warn. Henderson, Design Defect Litigation Revisited, 61 CoRnell L. Rev. 541, at $544 \mathrm{n} .18$ (1976). Presumably this argument could also be applied to the duty to 
crease after the correlation between the vaccine and the Guillain-Barré syndrome was publicized. ${ }^{86}$ The low percentage of the population participating in the program may have been due, however, to doubt that a swine flu epidemic would materialize. ${ }^{87}$ In addition, the impact of the risk of Guillain-Barré syndrome may have been especially great because the risk was unexpected, because the disease caused permanent paralysis or death in some cases, and because the incidents in which serious harm occurred were well publicized. ${ }^{88}$ As a consequence, the correlation between the immunization and the disease was probably overestimated by the public, at least when the risk was first discovered. The problems of the swme flu program thus present an atypical instance of adverse public reaction. In cases where a genuine risk of encountering the disease can be demonstrated, an objective summary of the risks and benefits of a more routine vaccination should not deter a potential recipient, especially one who has received such immunizations in the past without any significant side effects.

The vast majority of states have statutes that require most of the routine childhood immunizations prior to school entry. ${ }^{89}$ Normally a child undergoes a medical procedure only after a parent has given consent. $^{00}$ It can be argued, however, that when state law requires certam

obtain an informed consent. However, the commentator goes on to say that although several cases have hinted at the possibility of creating such an exception, no case has done so.

If a high value is placed on individual autonomy, a decision not to provide information to vaccine recipients is very difficult to justify. If the risk of disease were so high that widespread immunization became imperative, vaccine recipients would probably not be deterred by disclosure, for a realistic portrayal of risks and benefits would then convince most individuals of the need for immunization.

86. NewsweEk, Dec. 6, 1976, at 55. An opinion survey showed a rise in the percentage of the population that did not intend to be vaccinated following the publicity concerning the deaths of vaccine recipients. COMPTROLLER GENERAL's REPORT, supra note 17 , at $55-57$.

87. See COMPtroller General's Report, supra note 17, at 57-58. P. Parkman \& L. Harmison, supra note 25 , at 10.

88. See O'Toole, Why the Swine Flu Program Failed, Wash. Post, January 30, 1977, § C, at 3, col. 1; P. Parkman \& L. Harmison, supra note 25; Report on Health Information, supra note 20 , at 5-8.

89. Forty-seven out of fifty states have such requirements. Report on Consent, supra note 2 , at 24 , app. A.

Challenges to the constitutionality of laws requiring vaccination have consistently been rejected. See, e.g., Jacobson v. Massachusetts, 197 U.S. 11 (1905); Kleid v. Board of Educ., 406 F. Supp. 902 (N.D. Ky. 1976); Itz v. Perick, 493 S.W.2d 506 (Tex. 1973), appeal dismissed for want of a substantial federal question, 412 U.S. 925 (1973); Zucht v. King, 225 S.W. 267 (Tex. Civ. App. 1920), writ of error dismissed for want of a substantial federal question, 260 U.S. 174 (1922).

90. Because a child is not considered legally competent to consent, the parent or guardian is authorized to consent on the child's behalf. See Cobbs v. Grant, 8 Cal. 3d at 244, 502 P.2d at 10, 104 Cal. Rptr. at 514. Seventy percent of all immunizations are given to children. Report on Consent, supra note 2, at 49. 
immunizations as a prerequisite to school entry, informed parental consent is meaningless and should not be required. If the statute were compulsory in fact, as well as in name, this argument would be tenable. Such a truly compulsory statute would have few or no exemptions, all of which would be narrowly construed. Moreover, vaccination would be truly compelled-by force if necessary. No such statute has yet arisen, perhaps because when the perceived danger to public health becomes so great as to justify the use of coercion the individual's perception of that danger as a personal threat also is likely to increase. ${ }^{01}$

In fact, compulsory vaccination statutes are not so tightly written or enforced. Most states have statutory exemptions-some expressed in broad terms ${ }^{2}$ - which permit avoidance of immunization on medical, religious, or conscientious grounds. ${ }^{93}$ If a child is not within an exemption, the chosen remedy-exclusion from school-is not always enforced. ${ }^{94}$ Since the statutes preserve some elements of choice, the policy of individual autonomy should be effectuated by providing information to parents on the risks and benefits of vaccination.

The primciple that, at least where a choice is available, the information relevant to the exercise of that choice should be disclosed is supported by Reyes. There the defendant manufacturer asserted that a warning of the vaccine's risks would be futile simce polio vaccination was required for school entry. ${ }^{95}$ The court disagreed, pointing out that a warning might have led the plaintiff to obtain the Salk vaccine, which does not carry any risk of causing polio. ${ }^{06}$

Allowing nondisclosure where the vaccination is necessary for school entry might lead to confusimg disclosure requirements. Not every immunization routinely given to children is compulsory under state law. Mumps mimunizations, for example, are only required in two states. ${ }^{97}$ If informed consent were to be required with a mumps vaccination but not required for compulsory vaccinations, a parent whose child was to be immunized for measles, mumps, and rubella would be given information on numps but would not be given in-

91. In fact, if the risk of disease is great then it may well be that the risks of immunization would not be considered material.

92. For example, California law provides an exemption on the ground that the required exemption would be contrary to "personal belief." Act of Sept. 30, 1977, Ch. $1176, \S 2,1977$ Cal. Stats. (to be codified as Cal. Health \& SAFETY Code \$ 3380).

93. Report on Consent, supra note 2, at 50.

94. Although the federal government plans to institute a program designed to assure that at least 90 percent of the nation's youngsters are immunized by the fall of 1979, in the past many young people have not been immunized for childhood diseases and schools have not strictly enforced the school entry requirements. NEwsweEk, Sept. 19, 1977, at 98; see NEWSWEEx, Feb. 21, 1977, at 73.

95. 498 F.2d at 1293.

96. Id. at 1293 \& 1296.

97. Report on Consent, supra note 2, at app. A. 
formation on measles and rubella. The legitimacy and credibility of immunization programs could well be compromised by even such a limited appearance of duphicity. Thus, even in the case of "compulsory" vaccinations, the material risks and benefits of immunization should be disclosed.

\section{IV}

ACHIEVING THE GOAL OF OBTAINING INFORMED CONSENT TO IMMUNIZATION

Even when a physician or public health department has concluded that informed consent to immumization should be obtained, the best method of achieving that goal is not readily determinable. In a public health clinic the only feasible means of disclosing risks and benefits and alternatives to immunization seems to be a printed informed consent form. ${ }^{88}$ Tramed personnel should also be available to check for contraindications and answer questions. In contrast, the private physician can and should take time to discuss the information with the patient. In either context, the major problems are determining what information is material, conveying the material information in a comprehensible form, and providing a realistic picture of the risks and benefits of the vaccine. ${ }^{90}$

98. The Davis court, holding that the vaccine manufacturer was legally obligated to warn those vaccinated in mass immuuization programs of the vaccine's risks, stated that although a warning on the label of the vaccine bottle would not reach the vaccine recipient, "other means of communication such as advertisemeuts, posters, releases to be read and signed by recipieuts of the vaccine, or oral warnings were clearly available and could easily have been undertaken or prescribed by appellee." 399 F.2d at 131 .

Although the opinion suggests that advertisements or posters could be used to warn of the vaccine's risks, these methods are not well suited to a detailed disclosure of risks and benefits. Also, they do not insure that each vacciue recipient has been preseuted with the information and asked to acknowledge that he has read the information and believes he understands it. Therefore it is not surprising that the alternative of using a written warning has been adopted. Although an oral warning might be a more effective means of communication, it would be more time-consuming than a written warning.

If advertisements and posters are used in addition to the informed consent forms, they should not place so much emphasis on the beuefits of vaccmation that the impact of the information presented in the consent forms is substantially reduced. In products liability cases, overpromotion has been regarded as a ground for challenging the adequacy of the warnings. See, e.g., Stevens v. Parke, Davis \& Co., 9 Cal. 3d 51, 507 P.2d 653, 107 Cal. Rptr. 45 (1973); Love v. Wolf, 226 Cal. App. 2d 378, 38 Cal. Rptr. 183 (3d Dist. 1964), second appeal, 249 Cal. App. 2d 822, 58 Cal. Rptr. 42 (3d Dist. 1967).

99. A consent form similar to that used in the swine flu program has been developed for use with all oral polio vaccine purchased by the federal government. Report on Consent, supra note 2, at 30. The first form was produced in November 1976 and a revised draft form was produced in July 1977. In July 1977 the CDC also produced a consent form for the 1977-78 flu vaccine (a bivalent $A / V i c t o r i a$ and $B / H o n g$ Kong flu vacciue) and draft consent forms for measles, mumps, rubella, and DPT vaccmes. 
Although most informed consent cases do not require that the individual understand all the information disclosed, ${ }^{100}$ the duty to disclose should include a duty to present the information in a manner calculated to maximize comprehension. ${ }^{101}$ Developers of the CDC forms have attempted to use simple language, but the forms should be geared to

These draft forms may be revised, as the $\mathrm{CDC}$ wished to solicit comments from various health departments before mandating use of the forms. Interview with Dr. James Chin, Chief of the Infectious Disease Section, State of California Department of Health, in Berkeley, Califorma (Sept. 2, 1977). These draft consent forms, similar in format to the revised polio form, are one page long and contain information on the disease, the vaccine's possible side effects, and contraindications. Each form notes the lack of data on effects during pregnancy. The forms encourage questions and request reports of adverse reactions. These draft consent forms are on file with the California Law Review. Although the forms do disclose the significant risks associated with each vaccine, the consent forms could be improved by incorporating the suggestions discussed in tho text.

100. A few cases have implied that the duty of obtaining an informed consent carries an obligation to be certain that the patient understands the information presented. For example, in Berkey v. Anderson, 1 Cal. App. 3d 790, 803, 82 Cal. Rptr. 67, 76 (2d Dist. 1969) the court stated that informed consent "involves the duty of a doctor to properly explain the contemplated procedure and the question whether the patient reasonably comprehended the explanation." Similarly, in Mason v. Ellsworth, 3 Wash. App. 298, 312, 474 P.2d 909, 919 (1970) the court stated: "The critical determination to be made is whether the consent was given with an understanding of the reasons for or the necessity of the proposed procedure, its nature, and the reasonably foreseeable risks pertaining thereto." Yet the Mason court apparently did not mean to impose upon the doctor a duty to make the patient comprehend the information, for the court later recognized that "patients may only hear that which they want to hear, or be oblivious to what they are being told." Id. at 312, 474 P.2d at 919 . Realistically, it would secm impossible to be certain that each patient comprehended all the information presented.

In its 1972 "Statement of Patient's Bill of Rights," the American Hospital Association stated that the necessary disclosure should be "in terms the patient can be reasonably expected to understand." Miller v. Kennedy, 11 Wash. App. 272, 293, 522 P.2d 852, 866-67 (1974), affd per curiam, 85 Wash. 2d 151, 530 P.2d 334 (1975). Similarly, in Putensen v. Clay Adams, Inc., 12 Cal. App. 3d 1062, 1083, 91 Cal. Rptr. 319, 333 (1st Dist. 1970), the court restated the Berkey test, looking to whether the information could be "reasonably comprehended" rather than whether it was in fact reasonably comprehended.

Canterbury cautioned against the "tendency to imply that what is decisive is the degree of the patient's comprehension." Rather, the court emphasized that:

[T] he physician discharges the duty [to disclose] when he makes a reasonable effort to convey sufficient information although the patient, without fault of the physician, may not fully grasp it . . . the factfinding process on performance of the duty ultimately reaches back to what the physician actually said or failed to say.

464 F.2d at 780 n.15.

101. It is difficult to assess vaccinees' comprehension of the consent form. In one survey of individuals vaccinated in public swine flu immunization programs, $90 \%$ of the vaccine recipients recalled having received a formal document, and of that group 93\% stated that they believed they understood all or part of the information. P. Parkman \& L. Harmison, supra note 25. A recent field test of the CDC's new consent forms for childhood diseases, conducted in Los Angeles, revealed a startlingly low level of comprehension among parents who had read and signed the consent forms. One apparent problem was the fact that parents were more concerned with calming their 
an even lower reading level. ${ }^{102}$ Similarly, disclosure of too many details could be detrimental, since an overload of information results in lower comprehension. If the material risks and benefits are complex, important information should not be omitted, but it should be stated as clearly and simply as possible. ${ }^{103}$ Further explanation should always be available, and if translation of a form or reading the form to an individual is necessary, the service should be provided if at all feasible. ${ }^{104}$

The patient should be given candid information on both the benefits and risks of vaccination. If the vaccination is not recommended for particular classes of individuals, that fact should be clearly stated. ${ }^{105}$ When an alternative vaccine is available and its risks and benefits are significantly different froin those of the vaccine being considered, the risks and benefits of the other vaccine should be briefly described. ${ }^{100}$

children who were to be vaccinated than with carefully reading the consent form. Interview with Dr. James Chin, Chief of the Infectious Disease Section, State of California Department of Health, in Berkeley, California (Sept. 2, 1977). Perhaps consent forms should be distributed and read in one area and vaccinations should be given in another to help reduce distractions. Although it is unlikely that many will comprehend the information fully, most people should be able to attam a rough understanding of the risks and benefits if the disclosure is worded simply and in lay terms.

102. The revised polio form demonstrates recent attempts at simplification. For example, the heading has been changed from "ORAL POLIO VACCINE CONSENT FORM" to "TMPORTANT INFORMATION ABOUT POLIO AND POLIO VACCINE Please read this carefully." In discussing the risks of polio the earlier form stated, "About 10 percent of cases are fatal." The new form reads, "One person out of every 10 who get polio dies from it." See November 1976 oral polio consent form and July 1977 draft oral polio consent form, on file with the California Law Review.

103. The revised oral polio vaccine consent form omits the statement that the vaccine contains "live viruses" that have been attenuated "with the intent of giving protection without causing illness." Since this statement helped to explain the different risks of the Sabin live-virus and the Salk killed-virus vaccines, it should not have been omitted. The present form does disclose, however, that the alternative vaccine carries no risk of causing polio.

104. In some cases this may be necessary in order to make a reasonable effort to convey the material information. The swine flu consent forms were transiated into a variety of languages. P. Parkman \& L. Harmison, supra note 25, at 9 .

105. The consent forms all contain warnings to those for whom the vaccine is contraindicated. This information should reflect current recommendations by medical experts. For example, the first polio consent form explained that polio vaccine is mainly given to children as "there is thought to be a greater risk from the oral polio vaccine for adults." The new form specifically advises persons over 18 years of age not to take oral polio vaccine before checking with a doctor. Whereas the prior form recommended oral polio vaccination for adults traveling to a place where polio is common, the new form states that the (Salk) "injectable polio vaccine" is recommended for these individuals. See note 106 infra and accompanying text.

The new form also includes a section entitled "Warning-Some Persons Should Not Talke Oral Polio Vaccine Before Checking with a Doctor." In addition to the earlier forn's warning directed to cancer patients and those with particularly low resistance to infections, the new warning includes "[t]hose who live in the same household with any of the above persons" and "[t]hose who are sick right now."

106. Neither the first nor the revised oral polio vaccine consent form refers to 
Consent forms should also provide information that will allow the vaccine recipient to compare the risk of serious injury or death from the disease with the risk of serious injury or death from the vaccine. Although the current consent forms are quite detailed, it is often difficult or impossible to inake a comparison of risks and benefits based on the data they provide. The forms usually disclose the incidence of serious side effects resulting from the vaccine and the incidence of death or serious injury among those who contract the disease, ${ }^{107}$ but they do not provide figures on the statistical probability of contracting the disease. ${ }^{108}$ Instead they state that the disease was formerly coinmon and now occurs inuch less frequently due to widespread immumization. ${ }^{100}$ If it is possible to provide figures directly comparing the risk of serious harm froin the vaccine with the risk of serious harm from the disease, the forms should provide this information. ${ }^{110}$ The forms should also disclose how effective the vaccine is. A concrete statistic should be given if available, since it would aid assessment of the vaccine's benefits more than a general statement regarding the vaccime's effectiveness. ${ }^{111}$

the Salk vaccine by name. The original form referred to the Salk vaccine as a "killed polio vaccine"; the second form calls it an "injectable polio vaccine." The new form states that the injectable vaccine "has almost no risk of causing paralysis." Although the first form stated that the Salk vaccine was "available to a very limited extent," the revised form states that this vaccine "is not widely used in this country at the present time, but it is available." The new form encourages the vaccine recipient to ask questions about the Salk vaccine. This form also states that "[m]ost polio experts do not feel [the Salk vaccine] is as effective as the oral polio vaccine for controlling polio in the United States." Not surprisingly, no mention is made of the fact that this issue has been hotly debated. See Boffey, Polio: Salk Challenges Safety of Sabin's Live-Virus Vaccine, 196 SCIENCE 35, 35 (1977).

107. The first oral polio vaccine form stated that once in every five to ten million doses distributed, a person who received the oral poho vaccine or who came into contact with a vaccine recipient is permanently crippled or dies. In the second form the estimate is one in four milkon. The first form also stated that fewer than ten polio cases have occurred annually during the past five years; the new form states that fewer than twentyfive cases have occurred annually during that period. Significantly, neither form notes the evidence that all the cases of polio that have occurred in the United States in recent years may have been caused by the vaccine, since they were cases involving either vaccine recipients or those who had been in contact with vaccine recipients. See Boffey, supra note 106, at 35 .

108. The November 1976 polio form merely includes a statement that the risk of contracting polio at the present time is very low "even if you are not vaccinated" but that a numerical estimate of the risk cannot be given. The July 1977 revised form also simply describes the risk for those who are not immunized as "very low."

109. See July draft consent forms for polio, measles, mumps, rubella and DPT, on file with the California Law Review.

110. See, e.g., Davis v. Wyeth Laboratories, Inc., 399 F.2d at 130 (available data indicated a 0.9 chance per million that an individual over 20 years of age would contract polio from natural sources and a chance of less than one case per million that polio would be contracted from the vaccine, indicating that the risk of harm was roughly equal with or without vaccination).

111. The mumps, measles, and rubella forms all meet this criterion; those vaccines are described in the forms as $90 \%$ effective. The DPT form states that the tetanus 
The major area in which consent forms could be improved is the disclosure of benefits. The forms are increasingly successful in simply and forthrightly explaining the risks associated with the vaccimes. Yet on some forms the risks are so explicitly described and the benefits are summed up so briefly that the reader could easily conclude that the vaccime's risks are far too great to be worth taking. ${ }^{112}$

The direct benefits of immunization to the individual over the short term should be fully discussed. First, protection is especially important if the disease would be particularly dangerous to the vaccinee. ${ }^{113}$ Consent forms should identify high-risk individuals as clearly as possible and indicate whether vaccimation is especially recommended for these individuals. Second, immunization is especially important when the imdividual lives and works in an area where the risk of contracting the disease is high. Therefore the public health center should make available any information on local outbreaks of the disease. ${ }^{114} \mathrm{~A}$ recent assessment of the risk of outbreak is paticularly relevant in connection with the annual flu vaccime. ${ }^{115}$ Yet even with vaccines that

vaccine is $95 \%$ effective and that although the diptheria and pertussis vaccines "are not quite as effective, they still prevent most children from getting the disease and they make the disease milder for those who do get it." Similarly, both versions of the oral polio forms simply refer to the vaccine as "effective." If statistics on effectiveness are available, they should be disclosed.

The official 1977-78 flu vaccine form does not discuss the vaccine's effectiveness, probably because no claims of a high effectiveness rate can be made. A revised version of the flu form, in use in California, explains that the flu vaccine will offer protection against flu viruses that are similar to the viruses in the vaccine and that the vaccine contains those viruses that caused illness the previous year. Flu vaccine recipients should be informed that the vaccime's effectiveness is dependent on the experts' guess as to what flu virus will strike during the next flu season. See note 27 supra.

112. For example, in discussing the possible side effects of the DPT vaccine, the consent form states:

About 1 out of every 7,000 children who get the shots will have a more serious side effect such as high fever or a convulsion. They might also cry for several hours or go into shock and get pale. Rarely, about once in every 100,000 shots, inflammation of the brain (encephalitis) or brain damage may occur. Death may occur, even more rarely.

The form never makes a general statement to the effect that public health experts recommend that the vaccine be administered and that generally the benefits are believed to outweigh the risks. See July 1977 draft of DPT consent form, on file with the California Law Review.

113. See, e.g., the California version of the 1977-78 flu vaccine form, on file with the California Law Review. This form notes that influenza is particularly dangerous for the elderly and for those with chronic medical conditions and that flu vaccine is recommended for those groups.

114. The court in Davis noted that the plaintiff "resided in an area that not only was not epidemic but whose immediate past history of incidence was extremely low." 399 F.2d at 130. In Cunningham v. Charles Pfizer \& Co., 532 P.2d 1377, 1382 (Okla. 1974 ), the court noted the "considerable risk of contracting polio from natural sources" due to the epidemic in the area.

115. See P. Parkman \& L. Harmison, supra note 25, at 13-15. 
are adıninistered only once or in one series, the vaccine recipient would probably be inore eager to be imınunized if recent data indicated that the incidence of the disease in the area had been rising. ${ }^{116}$

The forms should also einphasize the nature of the benefit that results from widespread immunization. It is true that if any particular individual is not innuunized while others are, the individual will benefit from a low incidence of disease without incurring the risks of vaccination. Vaccinees should understand, however, that effective control of communicable diseases depends on inununizing a high percentage of the population. ${ }^{117}$ Even in cases where the risks of the vaccine nay well outweigh the benefits to the particular individual, knowledge of the inportance of maintaining widespread inmunization may persuade the vaccinee to be immunized.

Consent forms should also include brief, accurate statements of public health officials' recommendations. ${ }^{118}$ Positive statements by experts, although provided as information rather than as a direetive, would encourage individuals to be immunized. Generally, although the benefits of immunization should not be inischaracterized, they should be fully discussed, for without sufficient emphasis on the positive aspects of imnunization the consent forms will convey a very distorted picture.

When important information is not available, that fact should also be made clear. The consent forms have inproved in this area, particularly with respeet to the risks of vaccination for pregnant women. ${ }^{110}$

116. The courts in Davis, 399 F.2d at 130 , and Cunningham v. Charles Pfizer \& Co., 532 P.2d 1377, 1382 (Okla. 1974), apparently made this assumption. In other words, an individual is likely to be interested in the short-term risks and benefits, not simply the future protection resulting from immunization.

117. Through immunization, the spread of communicable diseases can be reduced, as the number of possible transmitters of the disease is reduced. Protection of the whole community resulting from immunization of a portion of the community is known as the "herd effect". See D. Salk \& J. Salk, The Control of Influenza and Poliomyelitis by the Use of Killed Virus Vaccines, at 6 (1976) (unpublished article).

The November 1976 oral polio vaccine consent form includes a brief warning to those who might decide not to be immuuized that "if we do not keep ourselves protected by vaccination, epidemics of polio are certain to return, and the risk of disease will be increased," and a statement that the very remote risk of permanent paralysis or death resulting from the vaccine or from contact with a vaccine recipient should be recognized but should also be balanced against present and future benefits of protection derived from immunization.

118. For example, the California version of the $1977-78$ flu vaccine consent form states that: "[T]he U.S. Public Health Service recommends that the population groups at high risk of complications from influenza-the elderly and those with chronic medical conditious-receive influenza vaccine each year prior to the flu season which usually starts about late October or November."

119. Rather than emphasizing the lack of evidence that vaccination would be harmful durimg pregnancy, the July 1977 oral polio vaccine form states that "doctors usually avoid giving any drugs or vaccines to pregnant women unless there is a specific need." 
Reassurance should not be provided if in fact the data is inconclusive. ${ }^{120}$ In addition, indication of known gaps in researchers' knowlledge could itself be informative, for it could aid the individual in evaluating the known data.

An important ineans of obtaining additional data is through reports by vaccine recipients. The current draft consent forms for childhood diseases ask that reactions be reported. This request is a valuable addition, for the information gathered in this inanner will help public health officials to disclose the vaccine's risks inore accurately to future vaccine recipients. The 1977-78 flu vaccine form, perhaps through an oversight, omitted the request for reports of adverse reactions. It does include the direction "IF YOU HAVE A SEVERE REACTION OR ONE LASTING MORE THAN 48 HOURS, SEE A DOCTOR." This type of warning may in fact reduce the risks of the vaccine by encouraging vaccine recipients to seek immediate treatment if an adverse reaction does occur. ${ }^{121}$ Such a warning should be included on all consent forms. ${ }^{122}$

The present consent forms encourage questions and then direct the individual to "ask us now or call your doctor or health department." The forms should tell the vaccine recipient to ask any questions before receiving the vaccimation, ${ }^{123}$ particularly since the individual is asked to sign a form saying that he has had an opportunity to ask questions and that his questions were answered to his satisfaction. ${ }^{124}$ Although health centers are not able to provide a doctor to discuss the risks and benefits with each patient, nurses and volunteer workers should be trained to answer questions, provide additional information on vaccines,

120. For example, the reassurance contained in the first swine flu consent form that the vaccine could be taken safely during pregnancy was inappropriate since in fact the data did not conclusively imdicate that the vaccine was safe or unsafe during pregnancy and since doctors generally avoid prescribing drugs for pregnant women unless there is a specific need. See the California version of the 1977-78 flu vaccine consent form, on file with the California Law Review.

121. See note 39 supra.

122. This warning should he printed in bold-faced type and capital letters in order to attract the reader's attention.

123. The California version of the $1977-78 \mathrm{flu}$ vaccine consent form specifically requests that questions be asked before the vaccination. Putting this notice in capital letters and bold-faced type is important, as it is then set off from other information on the form. Thus an individual who cursorily scans the relevant statistics will be likely to read at least this clause.

124. By signing, the vaccine recipient also indicates that he has read the form and believes that he understands the risks and benefits of the vaccine.

The information part of the sheet is detachable from the consent part and the individual is instructed to keep the information sheet as a record. The information may be helpful in the event of an adverse reaction, and the suggestion that the form be retained may encourage people to keep accurate records of the immunizations they and their children have received. 
and check that the vaccine is not contraindicated. A doctor should be available to answer any questions or deal with any problems that the nurses and volunteer workers are not trained to handle.

It is true that the process of obtaining informed consent to immunization will be time-consuming. Yet it must not be approached halfheartedly. Unless a real effort is made to educate vaccine recipients about the basic risks and benefits of vaccimes the entire informed consent process will be a colossal waste of time and money.

The preceding suggestions are generally applicable to the private physician as well as the public health clinic. A physician should disclose substantially the same information disclosed in the CDC consent form. ${ }^{125}$ A doctor may not wish to make quite as detailed a disclosure as that made in the forms, however, particularly where the patient does not desire a lengthy analysis of the risks. ${ }^{120}$ Since the consent forms are designed to answer all pertiment questions, they are more detailed than many patients might desire. The physician should at the very least convey her best estimate of the relative risks of being immunized and not being immunized and should discuss any alternative vaccine. ${ }^{127}$

Normally an oral disclosure and some discussion with the patient would seen to be the most effective way to communicate this information. The physician may wish to have copies of the CDC consent forms available, so that a patient could read the form either before or after talking with the doctor. Since an individualized disclosure is possible,

125. The cases sometimes refer to the obligation to make a reasonable disclosure of the risks within the doctor's knowledge. Williams v. Menehan, 191 Kan. 6, 8, 379 P.2d 292, 294 (1963); Natanson v. Kline, 186 Kan. 393, 350 P.2d 1093 (1960), rehearing denied, 187 Kan. 186, 354 P.2d 670 (1960). It seems, however, that a competent physician should be aware of the material risks involved in a medical procedure. Mason v. Ellsworth, 3 Wash. App. 298, 312 n.13, 474 P.2d 909, 918 n.13 (1970) stated that: "A physician is presumed to have knowledge of mherent risks. Thus a physician's claim that he was unaware of a reasonably foreseeable risk of the procedure is no defense to an action based on informed consent." In Canterbury the court suggested that one could only be obligated to disclose risks that one actually knows, but that it may be negligent not to be aware of certain risks. 464 F.2d at 787 n.84.

In the case of vaccines, the physician should be aware of the material risks. since the information can easily be obtained by reading the CDC informed consent forms and the vaccine package inserts.

126. Several cases have stated that the doctor need not disclose the risks where the patient specifically requests nondisclosure. See, e.g., Cobbs v. Grant, 8 Cal. 3d at 245, 502 P.2d at 12, 104 Cal. Rptr. at 516; Putensen v. Clay Adams, Inc., 12 Cal. App. 3d 1062, 1083-84, 91 Cal. Rptr. 319, 333 (1st Dist. 1970). The doctor should not assume that the patient has waived the right to know, however, unless a specific request is made.

127. The physician cannot fulfill the duty to disclose simply by offering to answer any questions the patient may have. In Canterbury the court emphasized that many patients may not know what questions to ask. The physician, therefore, should volunteer the information the patient needs to make an intelligent decision. $464 \mathrm{~F} .2 \mathrm{~d}$ at 783 n.6. 
the doctor should not rely solely on the form but should point out why the vaccine would or would not be particularly recominended for the particular patient. Of course the doctor should check that the vaccine is not contraindicated, rather than relying on the warning of contraindications in the printed form.

Where the patient is able to discuss the vaccine's risks and benefits with the doctor, there seems to be far less danger of deterrence caused by disclosure of risks. The doctor should be able to convey a reahistic picture of the risks and benefits, without exaggerating either the positive or negative aspects of immunization. The patient must be allowed to inake the decision and therefore should not simply be reassured that the vaccine's risks are outweighed by its benefits.

\section{CONCLUSION}

Disclosure of the risks and benefits of vaccines is becoming increasingly common in public health programs. This development was a response to products liability cases requiring vaccime manufacturers to provide warnings in order to enable "informed choice" by individuals vaccinated in mass immunization prograins. These cases did not inpose on manufacturers the duty to warn consumers vaccinated by private physicians. Under informed consent doctrine, however, the fact that a doctor has made an individualized medical judgment does not affect the duty of disclosure. Thus, despite the limit set on the manufacturer's duty to warn vaccime recipients, the medical practitioner's duty to disclose is the same in either the mass inmunization program or the private physician setting.

Under the legal standard of disclosure, the medical practitioner must inform the patient of any alternative vaccines and of the material risks and benefits of vaccimation. Due to the greatly reduced incidence of communicable diseases, the risks of immunization may approximately balance the benefits to the individual; thus many risks of vaccination are "material" when viewed in relation to the benefits. Under the medical standard of disclosure, customary medical practice rather than materiality establishes the required disclosure. A widespread practice of disclosing risks in public health programs will provide evidence that disclosure of vaccines' risks and benefits is required under the medical standard.

Informed consent case law emphasizes the right of the individual to be informed about proposed medical procedures, thus promoting the intelligent exercise of personal autonomy. Where vaccimations are required for school entry, personal autonomy is restricted, yet the policies that support disclosure still favor providing nuaterial information. 
Disclosure sufficient to enable informed choice should not significantly diminish the effectiveness of immunization programs as long as the information conveyed presents a realistic picture of the risks and benefits of vaccimation. Although the CDC's consent forms have been steadily improving, they do illustrate the danger of overemphasizing the risks of vaccination. In addition to being candid about risks, consent forms should clearly describe the protection the vaccine offers to the individual and the inuportance of maintaining widespread inmunization. Informed consent procedures should be developed with regard to the underlying purpose of informed consent-not emphasizing risks, but rather enabling an individual to make an educated decision on whether to undergo a medically recoinmended procedure.

Andrea Peterson Woolley†

$\dagger$ B.A. 1974, Stanford University; third year student, Boalt Hall School of Law. 